\title{
KARAKTERISASI SIFAT FUNGSIONAL KONSENTRAT PROTEIN IKAN SUNGLIR (Elagatis bipinnulatus)
}

\section{CHARACTERIZATION OF FUNCTIONAL PROPERTIES FISH PROTEIN CONCENTRATE OF RAINBOW RUNNER (Elagatis bipinnulatus)}

\author{
Frets Jonas Rieuwpassa ${ }^{1}$, Ely John Karimela ${ }^{1}$, Devitha Cindy Lasaru ${ }^{1}$ \\ ${ }^{1}$ Program Studi Teknologi Pengolahan Hasil Laut, \\ Politeknik Negeri Nusa Utara, Tahuna-Sulawesi Utara \\ Korespondensi: frets.jr@gmail.com
}

\begin{abstract}
Fish protein Concentrat (FPC) is a form of dry protein wich is extracted from fish meet using ethanol solvent. The aims of this research is to characterization of fish protein concentrate wich extraction using ethanol $90 \%$. There are some steps that we established to achieve the aims such as (1) FPC exctraction using etanol $90 \%$ with ratio $1: 3$ during 3 hours, (2) to determine of characterization of FPC. All data are given descriptively. Result show the mean of FPC rendement between 20\%. Characteristic base on FAO 1976 showed protein (85\%), fat (3,28\%), odor (2,11: strong fishy odor) and whiteness degree $(53,54 \%)$ based on the information this product chategorized as type B. water contain analysis $(6,34 \%)$, asses $(7,47 \%)$, functional properties: oil absorbant capacity $(2,48 \mathrm{~g} / \mathrm{g})$ and water absorbant capacity $(2,02 \mathrm{ml} / \mathrm{g})$. This product contained 9 essential amino acids and 6 non essential amino acids.
\end{abstract}

Keyword: amino acid, fish protein concentrate, rainbow runner

\begin{abstract}
ABSTRAK
Konsentrat protein ikan (KPI) adalah bentuk protein kering yang diekstrak dari daging ikan menggunakan pelarut etanol. Tujuan penelitian ini adalah karakterisasi konsentrat protein ikan sunglir yang diekstrak menggunakan pelarut etanol. Bahan utama yang digunakan dalam penelitian ini adalah daging ikan sunglir dan pelarut etanol teknis. Tahapan penelitian meliputi (1) ekstraksi KPI menggunakan pelarut etanol 90\% dengan perbandingan 1: 3 selama 3 jam, (2) menentukan standar mutu KPI ikan sunglir dan analisis asam amino. Data yang diperoleh dibahas secara deskriptif. Hasil penelitian menunjukkan bahwa nilai rata-rata rendemen KPI berkisar 20\%. Karakteristik sesuai standar FAO 1976 meliputi kadar protein (85,34\%), kadar lemak (3,28\%), bau (2,11 : bau ikan kuat) dan derajat putih (53,54\%) sehingga tergolong KPI tipe B. Analisis kadar air (6,34\%), kadar abu (7,47\%), sifat fungsional: daya serap minyak $(2,48$ $\mathrm{g} / \mathrm{g})$ dan daya serap air $(2,02 \mathrm{ml} / \mathrm{g})$. KPI mengandung 9 asam amino esensial dan 6 asam amino non esensial.
\end{abstract}

Kata kunci: asam amino, ikan sunglir, konsentrat protein ikan 


\section{PENDAHULUAN}

Salah satu hasil tangkapan perikanan di Kepulauan Sangihe adalah ikan sunglir. Data DKP Sangihe menunjukkan bahwa hasil tangkapan ikan sunglir pada tahun 2015 mencapai 26,35 ton/tahun. Di kalangan masyarakat Sangihe ikan sunglir dikenal dengan nama lokal 'mangganganu'. Pemanfaatan ikan ini masih sebatas konsumsi untuk pangan, padahal jenis ikan ini mudah diperoleh dipasar lokal setiap harinya. Kelimpahan hasil tangkapan ini dapat dijadikan sebagai bahan baku produk olahan perikanan maupun produk intermediate seperti surimi dan tepung protein ikan. Tepung ikan bisa berbentuk hidrolisis protein yang mengandung protein $>60 \%$ (Asare et al. 2018) dan konsentrat protein ikan (KPI). KPI adalah bentuk tepung protein yang diekstrak dengan menggunakan pelarut organik untuk mengeluarkan lemak dan dilakukan pengeringan (Ibrahim 2009; Rieuwpassa et al. 2013). Konsentrat protein dapat dimanfaatkan sebagai sediaan protein untuk ditambahkan ke dalam bahan pangan yang rendah protein.

Menurut FAO 1976, konsentrat protein ikan dibagi menjadi 3 (tiga) tipe, yaitu : Tipe A, kadar protein minimal 67,7\%, kadar lemak maksimal 0,75\%, tidak berbau ikan dan tidak berwarna (putih bersih). Tipe $\mathrm{B}$, kandungan lemak kurang dari 3\%, masih berbau ikan jika ditambahkan ke dalam bahan pangan. Tipe C, sama seperti tepung ikan tetapi cara pengolahannya dilakukan secara higienis, memiliki kandungan lemak $>10 \%$ dan masih berbau ikan. Kualitas KPI ditentukan oleh jenis pelarut organik yang digunakan. Pelarut organik yang umumnya digunakan dalam mengekstaksi konsentrat protein ikan adalah etanol. Koesoemawardani dan Nurainy (2008), Wiharja et al. (2013), dan Rieuwpassa et al. (2013) menggunakan pelarut etanol dalam mengekstraksi konsentrat protein ikan dan menghasilkan kandungan protein berkisar antara $70-80 \%$.

Selain pengaruh pelarut dalam menghasilkan KPI yang berkualitas, waktu dan teknik ekstraksi juga dapat memberikan pengaruh nyata terhadap karakteristik konsentrat yang dihasilkan. Menurut Rieuwpassa et al. (2013), waktu ekstaksi yang paling baik pada ekstraksi konsentrat dari telur ikan cakalang adalah 3 jam. Waktu ekstraksi harus diperhatikan, hal ini untuk menghindari kejenuhan pelarut. Penelitian ini bertujuan untuk mengkarakterisasi sifat fungsional dari konsentrat protein ikan sunglir yang diekstrak dengan pelarut etanol.

\section{METODE PENELITIAN}

Penelitian dilaksanakan pada bulan September-November 2018. Penelitian bertempat di Laboratorium Penanganan Hasil Perikanan Jurusan Perikanan dan Kebaharian Politeknik Negeri Nusa Utara. Analisis sampel dilakukan pada Laboratorium Preservasi dan Diversifikasi Pengolahan Hasil Perikanan IPB.

\section{Bahan}

Bahan utama yang digunakan adalan ikan sunglir yang diperoleh dari pasar Towo Tahuna, Kabupaten Kepulauan Sangihe-SULUT dan pelarut etanol teknis 90\%. Peralatan yang digunakan meliputi : kain saring, elenmeyer, corong, sudip, timbangan analitik, pisau, gelas ukur, blender, aluminium foil, dan wrapping.

\section{Tahapan}

\section{Persiapan bahan baku}

Ikan sunglir segar yang diperoleh dari pasar Towo Tahuna, dibawa ke Laboratorium Penanganan Jurusan Perikanan dan Kebaharian Politeknik Negeri Nusa Utara. Ikan sunglir disiangi untuk memisahkan isi perut, insang, dan sirip. Selanjutnya, di-fillet untuk memisahkan daging ikan dengan kulit dan tulang. Daging ikan dicuci dan dilumatkan. Siap untuk diekstraksi.

\section{Ektraksi konsentrat protein ikan}

Proses ekstraksi mengacu metode Rieuwpassa et al. (2013) yang dimodifikasi. Daging ikan diekstrak dengan menggunakan pelarut etanol dengan perbandingan $1: 3$ (b/v) selama 3 jam. Tiap jam pelarut diganti untuk mencegah kejenuhan. Setelah itu, disaring untuk memisahkan endapan dan cairan. Endapan dikeringkan pada oven pengering dengan suhu $40^{\circ} \mathrm{C}$ selama \pm 24 jam. Endapan ditepungkan dan ditimbang untuk mengetahui rendemen. 


\section{Analisis proksimat dan asam amino}

Pengujian Proksimat KPI berdasarkan metode AOAC (2005). Pengujian ini terdiri dari kadar protein, kadar lemak, kadar air, kadar abu, dan karbohidrat (by difference). Sedangkan kandungan asam amino dianalisis dengan bantuan HPLC sesuai metode AOAC (1995) tentang analisis komposisi asam amino bahan/sampel.

Derajat putih (Debusca et al. 2013)

Analisis warna dilakukan dengan Chromameter. Mula-mula alat dikalibrasi dengan warna putih sampai monitor menunjukkan nilai $L$, $a$, dan $b$ sesuai dengan nilai yang tertera pada warna putih standar. Selanjutnya sampel diletakkan dalam tabung dengan ditutupi lensanya dan nilai reflektan (L, a, dan b) terbaca pada alat pengukur. Perhitungan nilai derajat putih dilakukan dengan menggunakan rumus :

Derajat putih $(\%)=100-\sqrt{(100-L *)^{2}}+a^{* 2}+b^{* 2}$

Uji organoleptik (Soekarto dan Hubies 1982)

Pengujian organoleptik untuk sampel konsentrat protein ikan menggunakan uji skoring terhadap bau. Skor yang diberikan sebagai berikut : 1 = bau ikan sangat kuat, 2 = bau ikan kuat, 3 = bau ikan lemah, $4=$ bau ikan sangat lemah, dan $5=$ tidak berbau ikan. Para panelis berasal dari mahasiswa Teknologi Pengolahan Hasil Laut, berjumlah 30 penelis.

\section{Daya serap lemak (Beuchat 1977)}

Sampel sebanyak $1 \mathrm{~g}$ dimasukkan ke dalam tabung sentrifus lalu ditambahkan dengan $10 \mathrm{ml}$ minyak nabati, kemudian diaduk dengan spatula dan didiamkan pada suhu kamar selama 30 menit. Setelah itu disentrifus pada $3.000 \mathrm{rpm}$ selama 30 menit. Volume minyak yang bebas atau tidak terserap oleh sampel, diukur dengan gelas ukur. Perhitungannya sebagai berikut:

$\underset{(\mathrm{g} / \mathrm{g})}{\text { Daya } \operatorname{serap} \text { minyak }}=\frac{\text { Volume awal }- \text { Volume akhir }}{\text { berat sampel }}$

Daya serap air (Beuchat 1977)

Sampel sebanyak 1 g dimasukkan ke dalam tabung sentrifus lalu ditambah dengan $10 \mathrm{ml}$ akuades, kemudian diaduk dengan spatula dan didiamkan pada suhu kamar selama 30 menit. Setelah itu disentrifus pada $3.000 \mathrm{rpm}$ selama 30 menit. Volume air bebas atau yang tidak terserap oleh sampel diukur dengan gelas ukur. Perhitungannya sebagai berikut:

Daya serap air $(\mathrm{ml} / \mathrm{g})=$

$($ berat awal + air terserap $)-($ berat akhir + air tak terserap $)$ berat sampel

\section{Analisis data}

Data yang diperoleh diakumulasi dan dihitung nilai rata-ratanya. Perhitungan nilai rata-rata menggunakan bantuan Microsoft EXCEL 2013. Data dibahas secara deskriptif, menjelaskan dan membandingkan dengan hasil penelitian lainnya yang relevan.

\section{HASIL DAN PEMBAHASAN}

\section{Rendemen}

Hasil dari suatu proses pengolahan disebut rendemen. Rendemen memberi pengaruh terhadap nilai produksi secara ekonomi dan jumlah bahan baku untuk suatu proses produksi (Ramadhan 2013). Jumlah rendemen KPI yang dihasilkan dari ekstraksi $100 \mathrm{~g}$ daging ikan sunglir rata-rata berkisar 20\%. Hasil ini lebih tinggi dibandingkan hasil penelitian Koesoemawardani dan Nurainy (2008) yang memperoleh rendemen konsentrat protein ikan rucah sebesar $16.58 \%$. Tepung KPI ikan sunglir dapat dilihat pada Gambar 1.

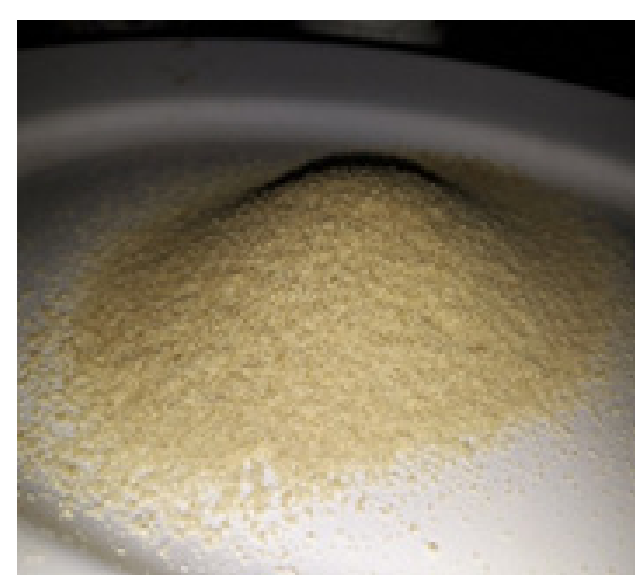

Gambar 1. Tepung KPI ikan sunglir 


\section{Karakteristik konsentrat protein ikan sunglir}

Hasil penelitian menunjukkan bahwa KPI dari ikan sunglir memiliki kualitas standar tipe B sesuai FAO 1976. Hal ini ditunjukkan dengan nilai kadar lemak yang masih tinggi dan masih memiliki bau ikan. Hasil pengujian dapat dilihat pada Tabel 1 .

Kadar protein KPI dari ikan sunglir tergolong tinggi, hal ini disebabkan oleh pelarut yang bersifat polar sehingga mampu menarik lemak dari daging ikan (Tirtajaya et al. 2008). Selain itu, teknik pergantian pelarut tiap 1 jam membantu menghilangkan lemak dari daging ikan. Kadar protein KPI dari daging ikan sunglir lebih tinggi dibandingkan konsentrat protein telur ikan calakalang yaitu 70,01\% (Rieuwpassa et al. 2013) dan konsentrat protein ikan rucah yaitu 77,15\% (Koesoemawardani dan Nurainy 2008). Proses ekstraksi yang berulang-ulang mampu membantu menurunkan lemak dari daging ikan pada proses pembuatan KPI. KPI dari ikan sunglir masih memiliki kadar lemak yang tinggi sehingga perlu dimaksimalkan proses ekstraksi dan penggunaan pelarut yang berbeda. Hasil penelitian Rieuwpassa et al. (2013) menunjukkan bahwa penggunaan pelarut isopropyl alkohol lebih efektif dalam mengekstraksi lemak dibandingkan pelarut etanol. Kadar lemak pada KPI ditentukan oleh jenis ikan, metode ekstraksi, cara mengeringkan dan lama ekstraksi (Balaswamy et al. 2007). Kualitas KPI ditentukan juga oleh tingkat keputihan atau derajat putih. Hasil penelitian menunjukkan bahwa KPI dari daging ikan sunglir memiliki derajat putih 53,54\%, masih lebih tinggi dibandingkan dengan konsentrat protein telur ikan cakalang (Rieuwpassa et al. 2013) dan lebih rendah dibandingkan konsentrat protein dari telur ikan kakap (Wiharja et al. 2013). Masih rendahnya tingkat keputihan tepung KPI disebabkan oleh lemak yang cenderung berwarna kekuningan dan masih adanya pigmen carotenoid pada lemak setelah diekstrak (Windsor 2001). Pengujian organoleptik bau KPI dari daging ikan sunglir menunjukkan bahwa KPI masih memiliki bau amis ikan yang kuat. Bau ini berasal dari lemak yang teroksidasi sehingga menimbulkan bau tengik atau amis dan proses ekstraksi yang belum maksimal. Menurut Rawdkuen et al. (2009), selain menghilangkan lemak proses ekstraksi juga bertujuan untuk menghilangkan darah, pigmen, dan bahan penyusun bau.

Analisis atau karakteristik lainnya yang diujikan untuk mengetahui kualitas konsentrat protein ikan sunglir adalah kadar air, kadar abu, daya serap minyak dan daya serap air. Hasil pengujian dapat dilihat pada Tabel 2 .

Tabel 1. Pengujian KPI sesuai standar mutu

\begin{tabular}{lc}
\hline \multicolumn{1}{c}{ Parameter } & Jumlah \\
\hline Kadar Protein (\%) & 85,43 \\
Kadar Lemak (\%) & 3,28 \\
Derajat Putih (\%) & 53,54 \\
Bau & 2,11 (bau ikan kuat) \\
\hline
\end{tabular}

Tabel 2. Hasil pengujian kadar air, abu, daya serap minyak, dan daya serap air

\begin{tabular}{lc}
\hline \multicolumn{1}{c}{ Parameter } & Jumlah \\
\hline Kadar Air (\%) & 6,34 \\
Kadar Abu (\%) & 7,47 \\
Daya serat Minyak (g/g) & 2,48 \\
Daya Serat Air (ml/g) & 2,02 \\
\hline
\end{tabular}


Kadar air suatu bahan menentukan umur simpan bahan tersebut. KPI ikan sunglir memiliki kadar air relatif rendah. Hal ini disebabkan proses pengeringan pada suhu $45^{\circ} \mathrm{C}$ mampu menguapkan air bebas. Kadar air KPI ikan sunglir (6,34\%) dan kadar abu $(7,47 \%)$ lebih tinggi dibandingkan kadar air (4,24\%) dan kadar abu (1,95\%) KPI dari telur ikan mas putih Cirrhinus mrigala (Chalamaiah et al. 2011). Menurut Chalamaiah et al. (2012), kadar air ratarata hidrolisis protein ikan berkisar antara 0,1-10,29\% sedangkan kadar abu rata-rata hidrolisis protein ikan berkisar antara 1,7625,94\%. Kemampuan menahan air dari luar dan dalam pada bahan pangan disebut sebagai daya serap air. Kemampuan ini bermanfaat untuk mengetahui daya pangan dalam mengikat air bebas dan terikat dalam bahan pangan sehingga memudahkan penyerapan dalam tubuh. KPI dari daging ikan sunglir memiliki kemampuan penyerapan air lebih rendah dibandingkan konsentrat protein telur ikan (Rieuwpassa et al. 2013) dan lebih tinggi dibandingkan dengan konsentrat protein telur ikan kakap (Wiharja et al. 2013). Kemampuan mengikat air oleh konsentrat protein ikan disebabkan oleh adanya asam-asam amino yang memiliki sifat polar. Santoso et al. (2009) menjelaskan bahwa daya serap minyak adalah kemampuan interaksi suatu bahan terhadap minyak. Hasil penelitian menunjukkan bahwa 2,48 g KPI dari daging ikan sunglir mampu menyerap $1 \mathrm{~g}$ minyak. Kemampuan penyerapan minyak ini masih lebih rendah dibandingkan hasil penelitian Pires et al. (2012) yang memperoleh tepung protein ikan Hake mampu menyerap minyak $4,67 \mathrm{~g} / \mathrm{g}$.

\section{Analisis asam amino}

Kualitas protein ditentukan oleh jenis asam amino penyusunnya. Asam amino terdiri dari asam amino esensial (asam amino yang dibutuhkan oleh tubuh karena tidak dapat memproduksi) dan asam amino non esensial (asam amino yang dapat diproduksi tubuh). KPI dari daging ikan sunglir memiliki total asam amino 643,96 $\mathrm{mg} / \mathrm{g}$ protein. Hasil uji komposisi asam amino KPI dari daging ikan sunglir dapat dilihat pada Tabel 3.

Tabel 3. Komposisi asam amino KPI sunglir

\begin{tabular}{llc}
\hline & \multicolumn{1}{c}{ Parameter } & Jumlah \\
\hline & Treonin & 35,40 \\
& Valin & 36,74 \\
& Histidin & 36,39 \\
& Arginin & 50,60 \\
Asam Amino Esensial & Lisin & 59,80 \\
& Phenilalanin & 36,21 \\
& Leusin & 57,48 \\
& Isoleusin & 34,19 \\
& Tirosin & 28,79 \\
\cline { 2 - 3 } & Jumlah & 375,63 \\
\hline & Asam Glutamat & 87,36 \\
& Asam Aspartat & 55,76 \\
Asam Amino Non-Esensial & Serin & 30,66 \\
& Glisin & 32,98 \\
& Alanin & 37,89 \\
& Prolin & 23,65 \\
\cline { 2 - 3 } & Jumlah & 268,32 \\
\hline Total & & $\mathbf{6 4 3 , 9 6}$ \\
\hline
\end{tabular}


Hasil penelitian menunjukkan bahwa KPI dari daging ikan sunglir memiliki 9 jenis asam amino esensial dengan lisin sebagai jumlah tertinggi dan memiliki 6 asam amino non esensial dengan asam glutamat sebagai jumlah tertinggi. Lisin adalah salah satu jenis asam amino esensial yang paling banyak terdapat pada konsentrat protein ikan (Sathivel et al. 2009; Rieuwpassa et al. 2013; Wiharja et al. 2013). Menurut Hussain et al. (2007), ikan mengandung asam amino lisin dalam jumlah yang tinggi. Fungi lisin pada tubuh antara lain : perbaikan otot, sebagai antibodi, penyerapan kalsium, sebagai enzim dan hormon. Salah satu penyebab rasa gurih pada ikan adalah asam amino glutamat. Jenis asam amino ini paling banyak terdapat pada protein ikan. Hasil penelitian Wiharja et al. (2013) menunjukkan bahwa asam glutamat pada konsentrat protein telur ikan kakap dan tuna masing-masing $112,15 \mathrm{mg} / \mathrm{g}$ dan 99,46 $\mathrm{mg} / \mathrm{g}$. Secara menyeluruh semua asam amino penyusun protein sangat penting untuk kebutuhan tubuh, kekurangan asam amino dapat menyebabkan gangguan kesehatan terutama perkembangan dan perbaikan jaringan tubuh dan otak.

\section{KESIMPULAN DAN SARAN}

\section{Kesimpulan}

Ekstraksi konsentrat protein dari daging ikan sunglir menghasilkan rendemen $20 \%$. Hasil pengujian standar mutu KPI menunjukkan konsentrat protein dari daging ikan sunglir tergolong Tipe B karena memiliki kadar lemak yang masih tinggi $(3,28 \%)$ tetapi memiliki protein yang cukup tinggi $(85,43 \%)$, masih memiliki bau amis ikan dan tingkat keputihan/derajat putih $(53,54 \%)$. Konsentrat protein dari daging ikan sunglir memiliki 15 jenis asam amino yang terdiri dari 9 asam amino esensial dan 6 asam amino non esensial. Lisin sebagai asam amino esensial dengan jumlah tertinggi $(59,80 \mathrm{mg} / \mathrm{g})$ dan asam glutamat sebagai asam amino non esensial dengan jumlah tertinggi $(87,36 \mathrm{mg} / \mathrm{g})$.

\section{Saran}

Saran dari penelitian adalah dilakukan pengujian lainnya seperti sifat emulsifier, kadar alkohol dan daya cerna in vitro tepung konsentrat protein ikan. Selain itu, aplikasi untuk bahan pangan juga dapat dilakukan.

\section{UCAPAN TERIMA KASIH}

Disampaikan terima kasih kepada Pusat Penelitian dan Pengabdian Kepada Masyarakat Politeknik Negeri Nusa Utara atas bantuannya memberikan dana penelitian internal sehingga penelitian ini boleh terlaksana dengan baik.

\section{DAFTAR PUSTAKA}

Asare SN, Ijong FG, Rieuwpassa FJ, Setiawati NP. 2018. Penambahan Hidrolisat Protein Ikan Lemuru (Sardinella lemuru) pada Pembuatan Biskuit. Jurnal Ilmiah Tindalung. 4(1) : 10-18.

Balaswamy K, Jyothirmayi T, Galla, DG. 2007. Chemical Composition and Some Functional Properties of Fish Egg (Roes) Protein Concentrate of Rohu (Labeo rohita). J. Food Sciences Technology-Mysore-. 44 : 293-296.

Beuchat LR. 1977. Functional and Electrophoretic Characteristics of Succinylated Peanut Flour Protein. J. Agric. Food Chem. 25(6) : 258-261. DOI: $10.1021 / \mathrm{jf60210a044.}$

Chalamaiah M, Balaswamy K, Galla NG, Prabhakara Galla PG, Jyothirmayi T. 2011. Chemical Composition and Functional Properties of Mrigal (Cirrhinus mrigala) Egg Protein Concentrates and Their Application in Pasta. J. Food Sci. Technol. 50(3) : 514-520. DOI: $10.1007 / \mathrm{s} 13197-$ 011-0357-5.

Chalamaiah M, Kumar BD, Hemalatha R, Jyothirmayi T. 2012. Fish Protein Hydrolysates: Proximate Composition, Amino Acid Composition, Antioxidant Activities and Applications: A review. Food Chem. 135(4) : 3020-3038. DOI: 10.1016/j.foodchem.2012.06.100.

Debusca A, Tahergorabi R, Beamer SK, Partington S, Jaczynski J. 2013. Interactions of Dietary Fibre and Omega-3-rich Oil with Protein in Surimi Gels Developed with Salt Substitute. Food Chem. 141(1) : 201-208. DOI: $10.1016 / \mathrm{j}$. foodchem.2013.02.111.

Hussain N, Akhtar N, Hussain S. 2007. 
Evaluation of Weaning Food Khitchri Incorporated with Different Levels of Fish Protein Concentrate. Animal Plant Sci. 17(1-2) : 12-17.

Ibrahim MS. 2009. Evaluation of Production and Quality of Saltbiscuits Supplemented with Fish Protein Concentrate. World J. Dairy Food Sciences. 4(1) : 28-31.

Koesoemawardani D, Nurainy F. 2008. Karakterisasi Konsentrat Protein Ikan Rucah. Prosiding Seminar Nasional Sains dan Teknologi II; 2008 November 17-18; Lampung, Indonesia. Lampung (ID): Lembaga Penelitian Universitas Lampung. hlm 32-43.

Pires C, Costa S, Batista AP, Nunes MC, Raymundo A, Batista I. 2012. Properties of Protein Powder Prepared from Cape Hake By-products. J. Food Eng. 108(2) : 268-275. DOI:10.1016/j. jfoodeng.2011.08.020.

Ramadhan W. 2013. Perubahan Mutu dan Pendugaan Umur Simpan Surimi Kering Beku Ikan Lele (Clarias Sp.) [Tesis]. Bogor: Sekolah Pascasarjana, Institut Pertanian Bogor.

Rawdkuen S, Samart SU, Khamsorn S, Chaijan M, Benjakul S. 2009. Biochemical and Gelling Properties of Tilapia Surimi and Protein Recovered Using an Acid-alkaline Process. Food Chemistry. 112 : 112-119. DOI: 10.1016/j.foodchem.2008.05.047.

Rieuwpassa FJ, Santoso J, Trilaksani W.
2013. Characterization of Functional Properties Fish Protein Concentrate of Skipjack Roe (Katsuwonus pelamis). J. Ilmu dan Teknologi Kelautan Tropis. 5(2) : 299-309.

Santoso J, Hendra E, Siregar TM. 2009. Pengaruh Substitusi Susu Skim dengan Konsentrat Protein Ikan Nila Hitam Oreochromis niloticus terhadap Karakteristik Fisiko-kimia Makanan Bayi. J. Ilmu Teknologi Pangan. 7(1) : 87-107.

Sathivel S, Yin H, Bechtel PJ, King JM. 2009. Physical and Nutritional Properties of Catfish Roe Spray Dried Protein Powder and Its Application in an Emulsion System. J. Food Eng. 95(1) : 76-81. DOI: $10.1016 / j$. jfoodeng.2009.04.011.

Soekarto ST, Hubeis M. 1982. Metodologi Penelitian Organoleptik. Bogor (ID): Institut Pertanian Bogor.

Tirtajaya I, Santoso J, Dewi K. 2008. Pemanfaatan Konsentrat Protein Ikan Patin (Pangasius pangasius) pada Pembuatan Cookies Coklat. J. Ilmu Teknologi Pangan. 6(2) : 87-103.

Wiharja SY, Santoso J, Yakhin LA. 2013. Utilization of Tuna and Red Snapper Roe Protein Concentrate as Emulsifier in Mayonnaise. Journal of Food Science and Engineering. 3 : 678-687.

Windsor ML. 2001. Fish Protein Concentrate. FAO online. http://www. FAO.org. [21 November 2018]. 